\title{
Biostimulation of Diesel Polluted Soil In Uturu-Abia State,Nigeria, Using Cattle Bone Powder
}

\author{
C.C. Dike ${ }^{1 *}$,I.Elekwa ${ }^{2}$, H.C.C., Maduka ${ }^{1}$, C.E.Ugwu ${ }^{1}$, P.N. Ogueche ${ }^{1}$, \\ C.J. Ofoegbu ${ }^{2}$ \\ ${ }^{I}$ Department of Human Biochemistry, College of Health Sciences, Nnamdi Azikiwe University, P.M.B. \\ 5001,Nnewi-Anambra State, Nigeria. Phone: 08038641948. Postal code:2345 \\ ${ }^{2}$ Department of Biochemistry, Abia State University-Uturu, P.M.B. 2000, Abia State, Nigeria
}

\begin{abstract}
The efficacy of cattle bone powder in biostimulation of farmland polluted with diesel in Uturu-Abia State, Nigeria, was investigated. This was done by estimating the bioloads which include: Total diesel degrading bacteria count(TDDBC),Nitrifying bacteria count(NBC), Phosphate solubilising bacteria count(PSBC) and Total heterotrophic bacteria count(THBC). The bioloads were estimated using the spread plate method at 24hrs,21days and 42days after biostimulation. The bioloads for THBC were from $2.6 \times 10^{4} \pm 0.1$ to $6.8 \times 10^{6} \pm 0.0$, which was the highest bacteria count among all the groups while the bioloads for NBC were from $1.6 \times 10^{3} \pm 0.3$ to $3.4 \times 10^{4} \pm 0.1$, which were the least among all the bacteria species determined. The results gotten showed that in the polluted portion without treatment (group" P"), the bioloads were decreasing significantly $(P<0.05)$ with time from, $1.9 \times 10^{3} \pm 0.1$ to $1.6 \times 10^{3} \pm 0.1$ for $N B C$, from $2.8 \times 10^{6} \pm 0.1$ to $2.6 \times 10^{4} \pm 0.1$ for $T H B C$, from $2.0 \times 10^{4} \pm 0.3$ to $1.9 \times 10^{3} \pm 0.0$ for $P S B C$. The bioloads for other treatment groups " $L$ ', ' $M$ ", " $H$ ", increased significantly $(P<0.05)$. The results gotten so far suggest that the population of the microorganisms in the polluted portions treated with cattle bone powder were stimulated as a result of the introduction of the cattle bone powder, hence, improvement on the fertility of the soil.

Key words: Bone powder, Biostimulation, Bioloads and Diesel pollution
\end{abstract}

\section{Introduction}

Soil is part of the terrestrial environment and support all terrestrial life forms [1].Crude oil or petroleum drilling began in Nigeria as far back as 1958 by Shell Company Ltd. in Eastern Niger Delta of Nigeria. Nigeria, being one of the nations that depend on crude as their major source of income has attracted a lot of foreign-oil investors in the crude oil industries presently apart from Shell Company Ltd. One of the major challenges which crude oil industries are facing presently is how to control crude oil pollution in the environment. These companies are always searching for cost effective methods of controlling this environmental pollution [2].Diesel, being one of the fractional distillation products of crude oil[3], is being used in trucks, trains and sub trains Engines [4],[5]. Using crude oil and its fractional distillation products have caused a lot of environmental pollution and modification of the environment [6], [7].

The environmental pollution caused by crude oil and its fractional distillation products have affected the soil ecosystem by adsorption to soil particles, induction of soil nitrogen deficiency, phosphorous and other physicochemical parameters of the soil[8]. [9] has reported that soil pollution influences the activities of enzymes in the soil. The soluble compounds in diesel have been reported to be toxic to aquatic organisms, other animals and human beings[10],[11],[12],[13]. Bioistimulation involves nutrient enhancement of microbial breakdown of organic waste[14]. Natural manure such as poultry manure,compost and artifitial manure such as fertilizer have been reported to improve microbial degradation of organic wastes[15], [16], [3]. Also, calcium supplements have been reported to support microbial growth, thus, enhancing biodegradation [12]. Such calcium supplements include: egg shells, periwinkle shell and animal bones.

\subsection{Justification of the work}

A lot of research had been carried out on the effects of crude oil spillage on soil and water but not mainly on the various fractions of crude oil such as diesel. This research intended to close this gap.

\subsection{Aim}

We aimed at evaluating the efficacy of cattle bone powder as supplements in biostimulation of diesel polluted soil by evaluating the predominant bacteria species in terms of prevalence, diversity and bioload, thereby determining whether the soil fertility improved with time. 


\section{Materials and methods}

\subsection{Description of study area}

This research was carried out in Abia State University,Uturu-Abia State,Nigeria.Uturu is under Isuikwuato Local Government(L.G.A.) Area, Abia State, Nigeria. It is located on latitude $7^{0} .6^{1}$ North and longitude $6^{0}$ East [17]. This area has a sandy/loamy soil rich enough for farming which is the main occupation of the people in the area. The area has two seasons,rainy and dry seasons. The rainy season is from AprilSeptember, while the dry season is from October to March every year.

\subsection{Sources of materials}

All chemicals used in this study were of analytical grade and purchased from Sigma Chemical Company, St. Louis, Missouri, USA. The cattle bone used was obtained from Nkwo Nnewi Abatoir, in Anambra State of Nigeria. The diesel used was obtained from Nigeria National Petroleum Co-operation (NNPC) mega station, Owerri-Imo State, Nigeria. 20litres capacity plastic container previously unused was obtained and thoroughly washed and rinsed with sterile distilled water.

\subsection{Soil preparation}

A portion of land at Abia State University botanical garden was cleared and divided into five experimental cells of $1 \mathrm{~m}^{2}$ and $1 \mathrm{~m}^{2}$ apart demarcated with wooden box. Two were used as controls-polluted without treatment and unpolluted(negative and positive controls).

\subsection{Pollution and treatment}

Three cells were polluted with diesel in the ratio of 3-2-1 litres for heavy,moderate and light pollution. These were treated with $490 \mathrm{~g} /$ cell of cattle bone powder.

\subsection{Soil sampling}

Sampling was done according to the treatments. $0-10 \mathrm{~cm}$ soil was augured and $5-11 \mathrm{~g}$ soil collected using spatula into a sterile bottle. This was done at three randomly selected spots and bucked together to give a complete sample. The samples were taken to Abia State University(ABSU) laboratory for onward analysis.

\subsection{Cattle bone application}

Cattle bone powder was applied using broadcasting and tilling method to the relevant cells.

\subsection{Microbiological analysis}

The various soils samples were cultured on different culture media including Nutrient Agar, McConkey agar, mineral salt Agar and other media to obtain the desired bacterial growth. The bioload was estimated using the method of [2], involving the spread plate technique of [18].

\section{Results and analysis}

The values for bioloads of various bacteria groups were represented in tables 1-3. These were subjected to statistical analysis using Duncan's Multiple range of tests and regression analysi as was described by [19]. There were significant increase in values from $24 \mathrm{hrs}$ to 42 days after biostimulation with bone powder among all the groups "L", "M", "H","P" and "0", for all the bacteria species, NBC,THBC,TDDBC and PSBC. Group "L" showed the highest increase from $2.9 \times 10^{4} \pm 0.7$ to $3.3 \times 10^{4} \pm 0.3,6.4 \times 10^{6} \pm 0.1$ to $6.7 \times 10^{6} \pm 0.1,3.7 \times 10^{3} \pm 0.1$ to $3.9 \times 10^{4} \pm 0.2$ for NBC,THBC,TDDBC PSBC from $24 \mathrm{hrs}$ to 42 days after biostimulation. This was followed by group " $\mathrm{M}$ " and " $\mathrm{H}$ " respectively. While the values for all the treatment groups increased significantly $(\mathrm{P}<0.05)$ towards the positive control group with time, the negative control(polluted without treatment) decreased significantly $(\mathrm{P}<0.05)$ with time when compared to other groups from, $2.2 \times 10^{6} \pm 0.1$ to $1.8 \times 10^{3} \pm 0.1,2.8 \times 10^{4} \pm 0.1 \quad 2.6 \times 10^{4} \pm 0.1,1.9 \times 10^{3} \pm 0.2$ to $1.6 \times 10^{3} \pm 0.3,2.0 \times 10^{4} \pm$ to $1.9 \times 10^{3} \pm 0.0$ for NBC, THBC,TDDBC and PSBC(Tables 1-3). There was no significant change in values for positive control throughout the period for $t$ all the bacteria species analyzed (see Tables 1-3).

\section{Discussion}

Bioload is one of the parameters used in investigating the population of microorganisms in soil, which determines the activities of soil microorganisms in the soil.Soil microorganisms have been reported by Mette and Anne [1] to be one of the indicators of soil health. The progressive decrease with time which was recorded in "P" group might be as a result of the effect of diesel pollution on the soil microorganisms in the portion of the soil. [7 ] has reported that crude oil pollution on soil affects the population of microorganisms in the soil adversely, thereby reducing the fertility of the soil. The increase in bioloads for other groups treated with cattle bone powder towards positive control suggests that the population of the microbial species investigated might 
have been stimulated as a result of the bone powder introduced in those portions of the soil. This was in line with the similar work done by [14], [20].Light polluted portion "L" recorded the highest increase of bioload among all the treatment groups followed by groups " $\mathrm{M}$ " and " $\mathrm{H}$ ". This might be as a result of the concentration of the contaminants in the portions of the soil. [12] has reported that the extent of crude pollution on the microbial population is dependent on the concentration of the contaminants in the crude oil.

However, among all the bacteria species investigated, THBC showed the highest bacteria count between $2.6 \times 10^{4} \pm 0.1$ to $6.8 \times 10^{6} \pm 0.2$.This suggests that THB is the most prevalent bacteria species in the soil. NBC showed the least values for bacteria count throughout the period, between $1.9 \times 10^{3} \pm 0.2$ to $1.6 \times 10^{3} \pm 0.3$. This also suggested that NB is the least prevalent specie.

\subsection{Conclusion}

The population of the microorganisms in the soil portions polluted and treated with bone powder was stimulated as a result of the bone powder introduced. Therefore, the use of bone powder is highly recommendable for use during bioremediation of diesel polluted soil since the result of this work has proved that it is efficient. Total heterotrophic bacteria (THB), Phosphate solublizing bacteria (PSB) and Total diesel degrading bacteria (TDDB) are to be used during bioaugumentation of diesel polluted soil. While nitrifying bacteria may not be used during bioaugumentation since it is the least prevalent.Research should be directed toward the effects of pollution of other fractional distillation products of crude oil, their biostimulation using bone powder and NPK-fertilizer.However,research should be directedtoward Using different types of organic manure such as poultry manure, wood ash, along with cattle powder to find out which one is more effective.

\section{References}

[1] N.N. Mette, and W. Anne, Microorganisms as indicators of soil health. NERT Technical Report. No. 388. Pp.7. July 2002.

[2] A.L. Mills, and R.R. Cowell, Enumeration of petroleum degrading marine and estuarine microorganisms by the most probable number method. Can. J. Microbial. Vol. 24,pp. 552. August 1998.

[3] O. Wei, L. Hong, V. Murygina, Y. Youngyong, X. Zengbe, and S. Kalyuzhnyi, Composting for remediation of oil sludge: a fieldscale study in China. Proc. Biochem. Vol. 40, pp.3763-3768. June 2005.

[4] D.G. Rushton, A.E. Ghally, and K. Martinel, Assessment of Canadian regulations and remediation method for diesel oil contaminated soils. Am. J. Appl. Sc. Vol. 4, issue 7, pp.465-478. Apr. 2007.

[5] J. Blondeau, J.G. Pon, S. Bresciani, and M. Reang, Analysis of selected diesel fuel markets in Canada. Agricultural and agrifood, Canada. Am. J. Appl. Sc. Vol.5, pp. 18-24. August 2004.

[6] C.O. Nweke, and G.C. Okpokwasili, Drilling fluid base oil. Biodegradation potential of a soil with Staphylococus species. Afr. J. Biotech. Vol. 2, issue 9, pp.293-295. Jan. 2003.

[7] V.O. Nwaugo, R.A. Onyeagba, and N.C. Nwachukwu, Effects of gas flaring on soil microbial spectrum in parts of Niger Delta area of Southern Nigeria. Afr. J. Biotech. Vol. 5, issue 19,pp.1824-1826. March 2006.

[8] J.C. Okolo, E.N. Amadi, and C.T. Odu, Effects of soil treatment containing poultry manure on crude oil. Degradation in a sandy loam soil. Appl. Ecology and Env. Res. Vol. 3, issue 1, pp. 47-53. March 2005.

[9] H. Li, Y. Zhang, C.G. Zhang, and G.Chen, Effects of petroleum containing waste water irrigation area. J. Env. Quali. Vol. 34, pp. 1073-1080. June 2005.

[10] F.J. Rivas, Polycyclic aromatic hydrocarbons sobbed on soils. A short review of chemical oxidation based treatment. J. Harzardous Materials. Vol. 138, pp. 234-251. Feb. 2006.

[11] J.M. Davis, C. Magnatus, and Y. Saniha, Isolation of petroleum degrading bacteria from various soil samples. Petroleum Microbiology. Vol. 21, pp. 17-20. Sept. 1996.

[12] V.O. Nwaugo, R.A. Onyeagba, S.O. Obiekezie, and O.C. Ugbogu, Effects of petroleum produced water in some parts of River State. Int. J. Biotech. Sc. Vol. 1,issue 1, pp. 26-32. Jan. 2006.

[13] G.C. Okpokwasili, and B.B. Okorie, Bioremediation potentials of microorganisms isolated from car engine lubricating oil. Tri. Int. Vol. 21,pp. 215-220. May 1988.

[14] L.O. Odukuma, and A.A. Dickson, Bioremediation of crude oil polluted tropical rain forest soil. Global J. Env. Sc. Vol. 2, issue 1, pp. 29-40. Feb. 2003.

[15] I. Ogboghodo, E. Erabor, T. Osemwota, and H. Isitekale, The effects of application of poultry manure to crude oil polluted soils on maize growth and soil properties. Env. Monitoring Assessment. Vol. 96, pp. 153-161. May 2004.

[16] A.H. Cuningham, Comparism of biostimulation in ex-situ treatment of diesel contaminated soil. Land Contaminated and Reclamation. Vol. 8, pp. 261-269. August 2000.

[17] F.A. Nkaa, C.I. Ogbonaya, and N.B. Onyike, Effect of different irrigation on physical and histochemical properties of Kenaf (Hibiscus cannabinus L.) grown in the field of Eastern Nigeria. Afr. J. Agri. Res. Vol. 2,issue 6, pp. 252-260.

[18] M. Chessbrough, "Laboratory manual for tropical countries in Tropical Health tech. $3^{\text {rd }}$ ed. Butterwoth, London, Apr. 2001, pp. 220-235.

[19] F. Nwaboka, Fundamentals of Statitics in Regression analysis, $4^{\text {th }}$ ed. University Press, Cambridge, July 1997, pp. 209-299.

[20] K. Lee, G.H. Tremblay, and E.M. Levy, Bioremediation application of slow release fertilizer on low energy shorelines in Proceedings of 1993 oil spill conference. American Petroleum Institute, Washington D.C. pp. 449-459. Apr. 1993.

Table 1. Bioload of top surface soil polluted with diesel 24hrs after biostimulation with cattle bone powder

\begin{tabular}{|l|l|l|l|l|l|}
\hline Bac.grp.(cfu/g) & $\mathrm{O}$ & $\mathrm{L}$ & $\mathrm{M}$ & $\mathrm{H}$ & $\mathrm{P}$ \\
\hline NBC & $3.4 \times 10^{4 \mathrm{c}} \pm 0.1$ & $2.9 \times 10^{4 \mathrm{c}} \pm 0.5$ & $2.4 \times 10^{3 \mathrm{~b}} \pm 0.1$ & $1.9 \times 10^{3 \mathrm{a} \pm} 0.3$ & $1.9 \times 10^{3 \mathrm{a}} \pm 0.2$ \\
THBC & $6.7 \times 10^{6 \mathrm{c}} \pm 0.1$ & $6.4 \times 10^{6 \mathrm{c}} \pm 0.2$ & $4.9 \times 10^{7 \mathrm{~b}} \pm 0.2$ & $3.1 \times 10^{6 \mathrm{a}} \pm 0.1$ & $2.8 \times 10^{6 \mathrm{~b}} \pm 0.1$ \\
TDDBC & $4.2 \times 10^{3 \mathrm{c}} \pm 0.1$ & $3.7 \times 10^{3 \mathrm{~b}} \pm 0.1$ & $2.3 \times 10^{3 \mathrm{a}} \pm 0.1$ & $2.3 \times 10^{2 \mathrm{a}} \pm 0.1$ & $2.2 \times 10^{3 \mathrm{~b}} \pm 0.1$ \\
PSBC & $4.4 \times 10^{4 \mathrm{c}} \pm 0.1$ & $3.6 \times 10^{4 \mathrm{~b}} \pm 0.7$ & $3.1 \times 10^{4 \mathrm{~b}} \pm$ & $2.4 \times 10^{3 \mathrm{a}} \pm 0.3$ & $2.0 \times 10^{4 \mathrm{~b}} \pm 0.3$ \\
\hline
\end{tabular}


Values are mean \pm standard deviations of triplicate determination. Values in the same row having the same letters are not significantly different. $(\mathrm{P}<0.05)$.

Table 2. Bioload of top surface soil polluted with diesel 21days after biostimulation with cattle bone powder

\begin{tabular}{|l|l|l|l|l|l|}
\hline Bac.grp.(cfu/g) & O & L & M & H & P \\
\hline NBC & $3.4 \times 10^{4 \mathrm{c}} \pm 0.1$ & $3.0 \times 10^{4 \mathrm{c}} \pm 0.1$ & $2.4 \times 10^{4 \mathrm{c}} \pm 0.0$ & $2.1 \times 10^{2 \mathrm{~b}} \pm 0.2$ & $1.8 \times 10^{3 \mathrm{a}} \pm 0.1$ \\
THBC & $6.8 \times 10^{6 \mathrm{c}} \pm 0.0$ & $6.5 \times 10^{6 \mathrm{c}} \pm 0.1$ & $5.4 \times 10^{7 \mathrm{~d}} \pm 0.1$ & $3.6 \times 10^{4 \mathrm{~b}} \pm 0.1$ & $2.7 \times 10^{5 \mathrm{a}} \pm 0.2$ \\
TDDBC & $4.2 \times 10^{3 \mathrm{c}} \pm 0.0$ & $3.8 \times 10^{4 \mathrm{c}} \pm 0.1$ & $2.5 \times 10^{3 \mathrm{~b}} \pm 0.1$ & $2.4 \times 10^{2 \mathrm{~b}} \pm 0.1$ & $1.9 \times 10^{3 \mathrm{a}} \pm 0.1$ \\
PSBC & $4.4 \times 10^{4 \mathrm{~d}} \pm 0.0$ & $4.0 \times 10^{4 \mathrm{c}} \pm 0.1$ & $3.3 \times 10^{4 \mathrm{c}} \pm 0.2$ & $2.6 \times 10^{2 \mathrm{~b}} \pm 0.2$ & $2.0 \times 10^{3 \mathrm{a}} \pm 0.3$ \\
\hline
\end{tabular}

Values are mean \pm standard deviations of triplicate determination. Values in the same row having the same letters are not significantly different. $(\mathrm{P}<0.05)$

Table 3. Bioload of top surface soil polluted with diesel 42days after biostimulation with cattle bone powder

\begin{tabular}{|l|l|l|l|l|}
\hline $\mathrm{O}$ & $\mathrm{L}$ & M & H & P \\
\hline $3.4 \times 10^{4 \mathrm{c}} \pm 0.3$ & $3.3 \times 10^{4 \mathrm{c}} \pm 0.3$ & $2.7 \times 10^{4 \mathrm{~d}} \pm 0.0$ & $2.3 \times 10^{3 \mathrm{e}} \pm 0.2$ & $1.6 \times 10^{3 \mathrm{a}} \pm 0.1$ \\
$6.8 \times 10^{6 \mathrm{c}} \pm 0.2$ & $6.7 \times 10^{6 \mathrm{c}} \pm 0.1$ & $5.6 \times 10^{7 \mathrm{~d}} \pm 0.4$ & $3.9 \times 10^{6 \mathrm{c}} \pm 0.1$ & $2.6 \times 10^{4 \mathrm{a}} \pm 0.1$ \\
$4.2 \times 10^{3 \mathrm{c}} \pm 0.0$ & $3.9 \times 10^{4 \mathrm{c}} \pm 0.2$ & $2.8 \times 10^{4 \mathrm{~d}} \pm 01$ & $2.6 \times 10^{3 \mathrm{a}} \pm 0.1$ & $1.8 \times 10^{3 \mathrm{~b}} \pm 0.1$ \\
$4.4 \times 10^{4 \mathrm{~d}} \pm 0.0$ & $4.1 \times 10^{4 \mathrm{c}} \pm 0.3$ & $3.5 \times 10^{4 \mathrm{a}} \pm 0.2$ & $2.7 \times 10^{3 \mathrm{~b}} \pm 0.4$ & $1.9 \times 10^{3 \mathrm{e}} \pm 0.0$ \\
\hline
\end{tabular}

Values are mean \pm standard deviations of triplicate determination. Values in the same row having the same letters are not significantly different. $(\mathrm{P}<0.05)$

\author{
Abbreviations and the meaning \\ TDDBC: Total diesel degrading bacteria count \\ NBC: Nitrifying bacteria count \\ PSBC: Phosphate solubilizing bacteria count \\ THBC: Total heterotrophic bacteria count \\ L: Light polluted cell with treatment \\ M: Moderate polluted cell with treatment \\ H: Heavy polluted cell with treatment \\ O: Positive control (unpolluted cell) \\ P: Negative control (polluted cell without treatment) \\ Bac. Grp: Bacteria group \\ NB: Nitrifying bacteria \\ TDDB:Total diesel degrading bacteria \\ Total heterotrophic bacteria \\ NNPC:Nigeria National Petroleum Co-Operation \\ PSB:Phosphate solubilizing bacteria.
}

